\title{
ОСОБЛИВОСТІ УЛЬТРАСТРУКТУРНОЇ РЕОРГАНІЗАЦІЇ ПЕРЕДСЕРДНИХ КАРДІОМІОЦИТІВ ПРИ ЕКСПЕРИМЕНТАЛЬНІЙ ТЕРМІЧНІЙ ТРАВМІ ТА ЗА УМОВ ЗАСТОСУВАННЯ ЛІОФІЛІЗОВАНИХ КСЕНОДЕРМОТРАНСПЛАНТАТІВ
}

\begin{abstract}
Резюме. Опікова травма у розвинених країнах є одним із найпоширеніших видів ушкоджень мирного часу. Лікування опіків визначається складністю та багатоплановістю, термічні ушкодження - одні з найнебезпечніших, вони призводять до руйнування складних білків - основи клітин і тканин органів. Ключову роль при розвитку та патогенезі опікової хвороби, що розвивається після термічної травми III ступеня, відіграє серцево-судинна система.

Мета дослідження - встановити закономірності ультраструктурних змін у передсердних кардіоміоцитах після тяжкої термічної травми за умов застосування ліофілізованих ксенодермотрансплантатів.

Матеріали і методи. Опік III ступеня наносили під кетаміновим наркозом мідними пластинами, нагрітими у кип'яченій воді до температури $97-100{ }^{\circ} \mathrm{C}$. Евтаназію тварин проводили після кетамінового наркозу шляхом декапітації. Розміри ділянки ураження склали 18-20 \% епільованої поверхні тіла морських свинок. Для електронно-мікроскопічного дослідження брали шматочки передсердь, фріксували у 2,5 \% розчині глютаральдегіду, постфріксували 1 \% розчином тетраокису осмію на фоосфатному бусрері. Подальшу обробку проводили згідно з загальноприйнятою методикою [3]. Ультратонкі зрізи, виготовлені на ультрамікротомі LKB-3, контрастували уранілацетатом, цитратом свинцю відповідно до методу Рейнольдса та вивчали в електронному мікроскопі ПЕМ-125 K.

Результати досліджень та їх обговорення. В експерименті вивчено субмікроскопічні зміни передсердних кардіоміоцитів після тяжкої термічної травми в умовах проведення ранньої некректомії та застосуванні ліофілізованих ксенодермотрансплантів для закриття опікової рани. Встановлено, що після опіку III ступеня відбуваються значні ультраструктурні зміни в передсердних кардіоміоцитах, ступінь ураження яких збільшувався в динаміці експерименту. При стадіях опікового шоку та ранньої токсемії у структурах серця розвиваються пристосувально-компенсаторні процеси, а при стадіях пізньої токсемії та септикотоксемії - наявні глибокі незворотні деструктивні зміни. Доведено, що використання ліофрілізованих ксенодермотрансплантатів після ранньої некректомії уражених тканин запобігає розвитку деструктивних змін у компонентах серця на ранніх термінах досліду, активізує регенераторні процеси скоротливих та ендокринних міоцитів передсердь на пізніх термінах експерименту. Висновки. Застосування ліосрілізованих ксенодермотрансплантатів позитивно впливає на перебіг регенераторних процесів та покращує стан ультраструктури передсердя в динаміці експерименту. На ранніх термінах досліду застосування ліофрілізованої ксеношкіри зменшує ступінь ушкодження цитоплазматичних мембран кардіоміоцитів передсердь, активізуються регенераторні процеси в клітинах.
\end{abstract}

Ключові слова: передсерді кардіоміоцити; ультраструктурні зміни; термічна травма; ліофілізовані ксенодермотрансплантати.

ВСТУП Проблема патогенезу опіків і патогенетичного обґрунтування ефективних способів терапії термічної травми залишається актуальною [2, 5, 6, 8, 9]. За даними ВОО3, опікові ураження займають третє місце серед інших травматичних ушкоджень, при цьому число постраждалих в промислово-розвинутих країнах постійно зростає. Опікові травми часто трапляються як в побуті, так і на виробництвах, а також при військових діях, унаслідок горіння бойової техніки та при використанні запалювальних сумішей $[5,9]$. Відомо, що опіки шкіри, глибокі та великі за площею, спричиняють розвиток опікової хвороби, яка супроводжується значними структурними та метаболічними порушеннями в системах та органах організму, в тому числі у серці $[1,2,4,6,7,9]$. В основі цих змін вагоме місце займає ушкодження зовнішнього покриву, яке стає джерелом екзогенної інтоксикація організму, втрати води та електролітів. Тому важливим $є$ відновлення шкірного покриву в найкоротші терміни [8]. У комбустіології для тимчасового закриття ранових поверхонь застосовують ліофрілізовані ксенодермотрансплантати. Накладання ксеношкіри на рану, очищену від змертвілих клітин, попереджує прогресування інтоксикації в організмі 3 вогнища ураження, зменшує втрати води, білків та мікроелементів із ранової поверхні й стимулює регенерацію шкіри, що, у свою чергу, позитивно впливає на морфоорункціональний стан органів опеченого організму $[10,11]$. Проте в науковій літературі недостатньо морфологічних досліджень про вплив тяжких опіків на ультраструктуру кардіоміоцитів в умовах застосування ксенодермотрансплантатів.
Метою дослідження було встановити закономірності ультраструктурних змін у передсердних кардіоміоцитах після тяжкої термічної травми за умов застосування ліофрілізованих ксенодермотрансплантатів.

МАТЕРІАЛИ І МЕТОДИ Досліди проведено на 48 статевозрілих морських свинках, яких утримували у стандартних умовах віварію на збалансованому харчовому раціоні. Усі маніпуляції із тваринами проводили з дотриманням правил Європейської конвенції про захисту хребетних тварин, що використовуються для дослідних та інших наукових цілей (Страсбург, 1986) та Загальних етичних принципів експериментів на тваринах (Київ, 2001).

Тварин поділили на 3 групи: перша - інтактні тварини (6 особин), друга - щури з опіковою травмою (24 особин), третя - тварини 3 опіковою травмою, яким провели ранню некректомію з подальшим закриттям ран ліофілізованими ксенодермотрансплантатами (18 особин). Термічну травму наносили під загальним ефірним наркозом водяною парою на епільовану поверхню шкіри спини протягом 1 хв. За таких умов розвивався опік III ступеня. Площа ураження становила 18-20 \% поверхні тіла тварини. Ранню некректомію ушкоджених ділянок шкіри проводили на 2 добу після нанесення опіку. Рану, яка утворилась, покривали ліофілізованими ксенодермотрансплантатами. Піддослідних тварин другої групи декапітували на 1; 7; 14 та 21 доби експерименту (відповідно до стадій опікового шоку, ранньої і пізньої токсемії та септикотоксемії опікової хвороби). Тварин третьої групи декапітували на 7; 14 та 21 доби експерименту. 
Для електронно-мікроскопічного дослідження забрані шматочки передсердь фріксували у 2,5 \% розчині глютаральдегіду, посторіксували 1 \% розчином тетраокису осмію на фросфатному буфері. Подальшу обробку проводили згідно із загальноприйнятою методикою [3]. Ультратонкі зрізи, виготовлені на ультрамікротомі LKB-3, контрастували уранілацетатом, цитратом свинцю відповідно до методу Рейнольдса та вивчали в електронному мікроскопі ПЕМ-125 К.

РЕЗУЛЬТАТИ ДОСЛІДЖЕНЬ ТА ЇХ ОБГОВОРЕННЯ На першу добу експерименту, що відповідає стадії опікового шоку, результати електронно-мікроскопічних досліджень показали, що у передсердних міоцитах виникли зміни в енергетичному апараті клітини. Це проявлялось гіпертрофрією більшості мітохондрій, частковою редукцією їх крист та просвітленням матриксу, що свідчить про активацію енергетичного обміну в клітині. Збоку скоротливого апарата кардіоміоцитів спостерігали локальне потовщення і розпушення міофрібрил, подекуди з частково фррагментованими міофріламентами. Проте поширення таких змін у цей термін досліду було незначним. У період опікового шоку виявлено дегрануляцію більшості міоендокринних клітин серця. Лише у деяких міоцитах виявлено поодинокі дрібні гранули, які зосереджувались переважно біля сарколеми. Мала кількість специфрічних секреторних гранул у цитоплазмі міоцитів передсердь свідчить про активне виведення ПНУП із клітини у кровоносне русло (рис. 1).

Результати субмікроскопічних досліджень кардіоміоцитів передсердь на 7 добу експерименту показали збільшення внутрішньоклітинних змін, які виникли внаслідок порушення кровопостачання серця. Ці зміни відображались гіпертрофрією більшості мітохондрій, просвітленням їх матриксу та ушкодженням крист. Деякі 3 цих органел містили зруйновані ділянки зовнішньої мітохондріальної мембрани. Проте поряд із ушкодженими органелами виявлялись мітохондрії з помірними структурними змінами, у яких зовнішня і внутрішня мембрани зберігали свою цілість. Зміни скоротливого апарату клітини проявлялись витонченням міофрібрил та частковим їх лізисом, виявлено ділянки перескорочення з невпорядкованим розташуванням саркомерів. У цей термін екс-

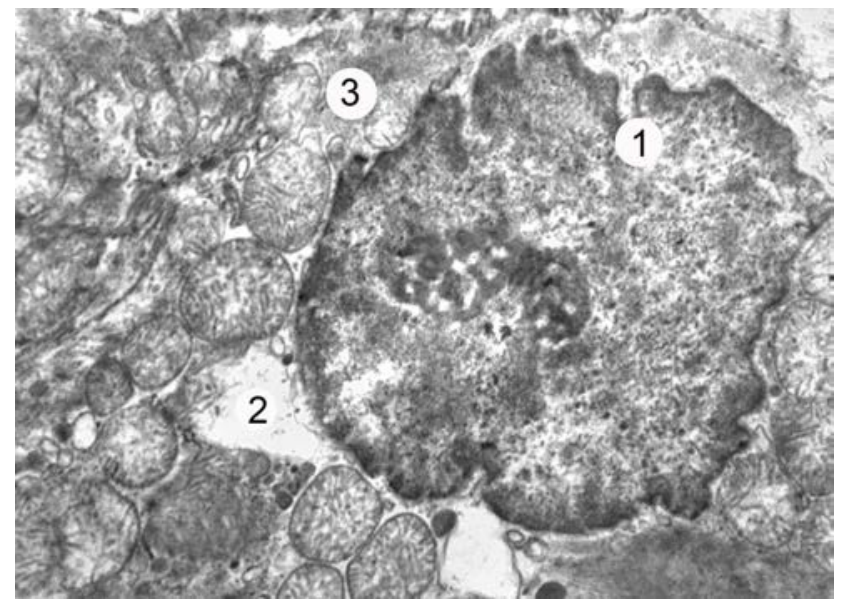

Рис. 1. Фрагмент кардіоміоцита лівого передсердя через добу після термічної травми: 1 - глибокі інвагінації каріолеми; 2 - мітохондрії з просвітленим матриксом; 3 - дегранульована цитоплазма. x14 000. перименту, порівнюючи з попереднім терміном, спостерігали активацію синтетичних процесів у клітині, які проявлялись розширенням канальців ендоплазматичної сітки, гіпертрофрією комплексу Гольджі та збільшенням кількості прогормону в клітині. Скупчення специфічних секреторних гранул у перинуклеарній частині цитоплазми міоендокриноцитів передсердь свідчить про те, що в клітині проходять процеси синтезу та накопичення секрету. Отже, встановлені субмікроскопічні зміни в кардіоміоцитах відображають перебіг у них пристосувально-компенсаторних реакцій.

Результати досліджень передсердних кардіоміоцитів у пізні терміни експерименту виявили наростання у них дистрофрічних змін. На 14 добу експерименту ці зміни проявлялись ущільненням ядер, зростанням числа і глибини інвагінацій каріолеми. Більшість мітохондрій була гіпертрофованою, у них виявлено зруйновані та фррагментовані кристи, розширені міжмембранні простори та локально просвітлений матрикс. У деяких мітохондріях спостерігали також ушкодження зовнішньої мембрани. Зміни скоротливого апарату проявлялись витонченням і лізисом міофрібрил та порушенням упорядкованого розташування саркомерів. Подекуди була фррагментація міофрібрил. Спостерігали розширення цистерн та вакуолізацію комплексу Гольджі. Кількість специорічних секреторних гранул у перинуклеарній зоні значно зменшилась, поодинокі гранули були біля сарколеми та між міофрібрилами (рис. 2).

На 21 добу досліду встановлено наростання деструктивних змін, які часто були незворотними. Більшість кардіоміоцитів мала пікнотично змінені ядра 3 електроннощільною каріоплазмою та слабовираженим перинуклеарним простором. Глибокі, деструктивні зміни у мітохондріях проявлялись їх гіпертрофрією, порушенням цілості зовнішньої і внутрішньої мембран, руйнуванням більшості крист, просвітленням їх матриксу. Значно ушкодженим був скоротливий апарат клітини. Це проявлялось фррагментацією і лізисом міофрібрил, ушкодженням міофіламентів, порушенням упорядкованого розташування саркомерів. У цитоплазмі передсердних кардіоміоцитів не виявлено специсрічних секреторних гранул. При цьому були значні деструктивні зміни ендоплазма-

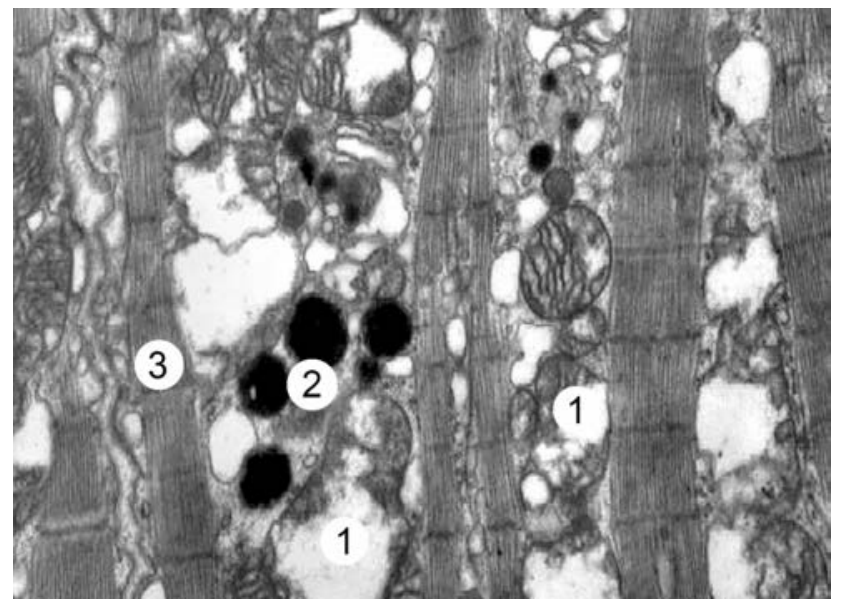

Рис. 2. Субмікроскопічні зміни передсердного кардіоміоцита через 14 діб після опікової травми: 1 - мітохондрії з ушкодженими кристами; 2 - секреторні гранули; 3 - гранули між міофібрилами. x16 000 
тичної сітки та комплексу Гольджі, що проявлялись розширенням, вакуолізацією та фррагментацією їх структурних компонентів. Відсутність гранул у цитоплазмі міоендокринних клітин передсердь та деструкція компонентів синтетичного апарату в цих клітинах свідчать про припинення секреції передсердного натрійуретичного пептиду та втрату здатності серця надалі здійснювати регуляторний влив на водно-електролітний баланс організму.

Результати дослідження ультраструктури передсердних міоцитів тварин третьої експериментальної групи показали, що проведення ранньої некректомії із подальшим закриттям рани ліофрілізованими ксенодермотрансплантатами вже на 7 добу експерименту забезпечує краще збереження їх структурних компонентів порівняно з тваринами другої групи. У багатьох кардіоміоцитах ядра утворювали значні інвагінації каріолеми, у них були збільшені ядерця, у каріоплазмі переважав еухроматин і рибосомальні гранули, що свідчить про активацію ядер. Цитоплазматичні зміни були менш виражені порівняно 3 тваринами другої експериментальної групи. Міофібрили мали відносно добре збережені саркомери і міофіламенти, лише на окремих ділянках спостеріли їх витончення і лізис. У деяких мітохондріях виявлено частково зруйновані кристи і просвітлений матрикс. У цей термін встановлено розширення канальців ендоплазматичної сітки та цистерн комплексу Гольджі, збільшення вакуолей. Кількість секреторних гранул в клітинах була низькою. Вони розміщувались невеликими групами у навколоядерній зоні саркоплазми, поодиноко між міосрібрилами та біля сарколеми (рис. 3).

При проведених електронно-мікроскопічних дослідженнях передсердних кардіоміоцитів на 14 добу експерименту встановлено, що у клітинах переважають регенераторні процеси над деструктивно-дегенеративними. Це проявляється меншим ушкодженням цитоплазматичних та ядерних мембран порівняно з тваринами другої групи. Ядра були збільшені в розмірі, в них переважав еухроматин та наявні рибосомальні гранули у каріоплазмі. В саркоплазмі кардіоміоцитів передсердь деструкція органел була помірною. У ній було багато рибосом і полісом та мало аутофагосом. Виявлено помірну деструкцію міофібрил, вони зберігали чітку саркомерну будову. Для мітохондрій характерними були гетероморфні зміни, які проявлялись їх гіпетрофрією та гіперплазією. Канальці ендоплазматичної сітки та цистерни комплексу Гольджі були помірно розширені. В цитоплазмі збільшилась кількість секреторних гранул, вони розміщувались біля ядра, частково між міофібрилами та біля плазмолеми. Це свідчить про активний перебіг синтезу натрійуретичного гормону міоцитами.

Проведені електронно-мікроскопічні дослідження на 21 добу експерименту показали, що застосування для закриття ран ліофілізованих ксенодермотрансплантатів має виражений позитивний ефект і сприяє оновленню внутрішньоклітинних структур серця. У більшості кардіоміоцитів передсердь ядра були структурно незмінені. У саркоплазмі кардіоміоцитів не виявлено суттєвих змін скоротливого апарату. Міофібрили зберігали нормальну структуру, вони упорядковано розташовувались в складі саркомерів. Тільки на окремих ділянках були їх витончення, розволокнення та частковий лізис. Для мітохондрій, як і в попередній термін досліду, характерні гетероморфні зміни. У більшості клітин ці органели мали чітко контуровані кристи та зовнішню мембрану. Проте в деяких клітинах спостерігали мітохондрії із частковим руйнуванням крист та локальним просвітленням матриксу. На 21 добу експерименту не виявлено суттєвих змін у структурах ендоплазматичної сітки і комплексу Гольджі, канальці та цистерни цих органел мали помірні просвіти. Виявлено значне скупчення специфрічних секреторних гранул біля ядра та невеликі групи гранул, які розташовувались між міофрібрилами та біля сарколеми. Ці гранули мали різні розміри та щільність, що свідчить про відновлення фразного характеру ендокринної фрунції міоцитів серця. В цей період досліду встановлено нормалізацію міжклітинних просторів та контактів. Вставні диски мали характерний для них звивистий хід, вони чітко контурувались та мали неушкоджені десмосомальні та щілинні контакти (рис. 4).

ВИСновкИ 1. Результати проведених електронномікроскопічних досліджень тварин із тяжкою термічною травмою показали, що глибокі та великі за площею опіки шкіри викликають морфофрункціональні зміни в передсердних кардіоміоцитах, глибина ушкодження яких знаходиться в прямій залежності від стадії опікової хвороби.

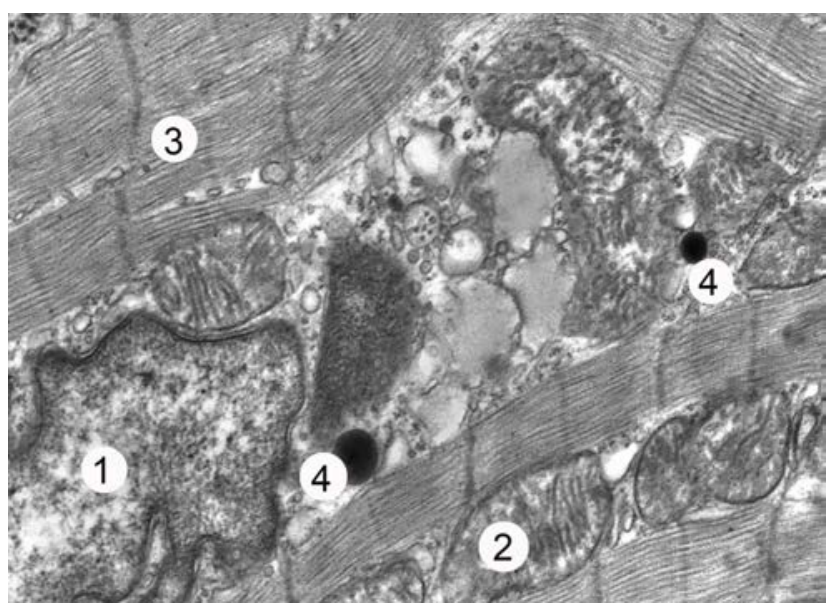

Рис. 3. Фрагмент передсердного кардіоміоцита через 7 діб після термічної травми за умов застосування ліофілізованих ксенодермотрансплантатів: 1 - ядро; 2 - мітохондрії; 3 - міофібрили; 4 - секреторні гранули. х20 000 .

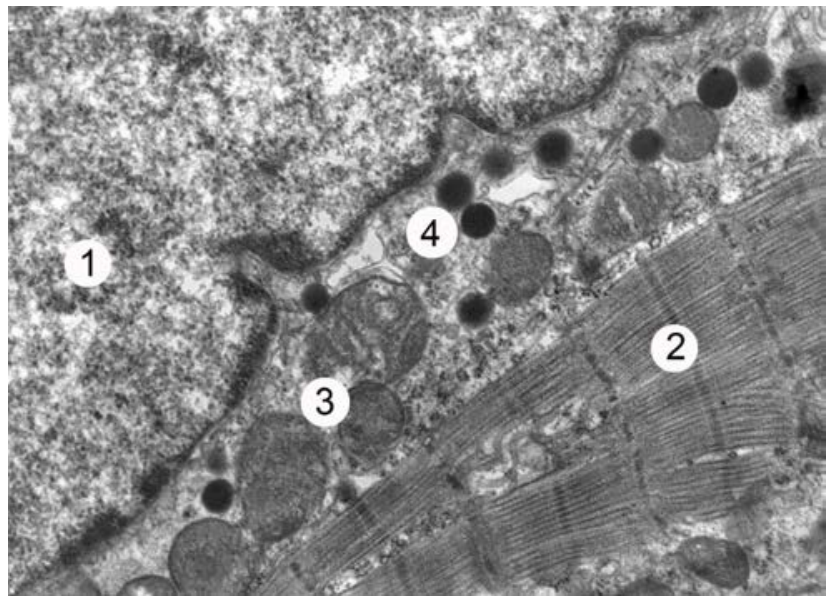

Рис. 4. Фрагмент пердсердного кардіоміцита через 21 добу після термічної травми за умов застосування ліофілізованих ксенодермотрансплантатів: 1- ядро; 2 - міофрібрили; 3 - мітохондрії; 4 секреторні гранули. х21 000 . 
2. У ранні терміни після термічної травми (1; 7 доби - стадії шоку та ранньої токсемії) ультраструктурні зміни передсердних міоцитів характеризуються пристосувально-компенсаторними процесами та ознаками пригнічення регенерації на клітинному і субклітинному рівнях. У віддалені терміни після термічних уражень (14 і 21 доби стадії пізньої токсемії та септикотоксемії) розвиваються глибокі деструктивні зміни структурних компонентів передсердь.

3. Результати проведених досліджень показали, що застосування ліосілізованих ксенодермотрансплантатів позитивно впливає на перебіг регенераторних процесів та покращує стан ультраструктури передсердя в динамі- ці експерименту. В ранній термін досліду (7 доба) застосування ліофрілізованої ксеношкіри зменшує ступінь ушкодження цитоплазматичних мембран кардіоміоцитів передсердь, активізуються регенераторні процеси в клітинах. На 14 і особливо 21 доби досліду використання ліофілізованої ксеношкіри сприяє активному перебігу регенераторних процесів, що приводить до покращення ультраструктури передсердних кардіоміоцитів та відновлення в них секреторного циклу.

Перспективи подальших досліджень У подальших дослідженнях планується з'ясувати морфологічний стан передсердь серця при термічній травмі з використанням інших коригувальних препаратів в експерименті.

\section{СПИСОК ЛІТЕРАТУРИ}

1. Структурные трансформации во внутренних органах при инсузионной терапии ожоговой болезни / В. Г. Черкасов, А. И. Ковальчук, И. В. Дзевульская [и др.] // Медична наука України. - 2015. - Т. 11, № 3-4. - С. 4-11.

2. Evers, L. H. 2010. The biology of burn injury / L. H. Evers // Exp Dermatol. -2015. - Vol. 19, No. 29. - P. 777-783 doi:10.1111/ j.1600-0625.2010.01105.X

3. Горальський Л. П. Основи гістологічної техніки і морфрофункціональні методи досліджень у нормі та при патології / Л. П. Горальський, В. Т. Хомич, О. І. Кононський. - Житомир : Полісся, 2011. - 288 с

4. Using the injury severity score to adjust for comorbid trauma may be double counting burns: implications for burn research / J. C. Janak, M. S. Clemens, J. T. Howard [et al.] // Burns. - 2018. - Vol. 44, Issue 8. - P. 1920-1929. doi: 10.1016/j.burns.2018.03.012

5. Jayme A. Curbing inflammation in burn patients / A. Jayme, Jr. Farina // Int. J. of Inflamm. - 2013. Article ID 715645, 9. doi: $10.1155 / 2013 / 715645$

6. Jeschke M. G. Inflammation and the host response to injury collaborative research program. Morbidity and survival probability in burn patients in modern burn care / M. G. Jeschke, R. Pinto, R. Kraft /I Crit. Care. Med. - 2015. - Vol. 43, No. 24. - P. 808-815.

7. Multiple organ failure as a cause of death in patients with severe burns / O. Kallinen, K. Maisniemi, T. Bohling [et al.] // J. Burn Care Res. - 2012. - Vol. 33 (2). - P. 206-211. doi: 10.1097/ BCR.0b013e3182331e73

8. New technologies in global burn care - a review of recent advances / L. Kearney, E. C. Francis, A. J. Clover // Int. J. Burns Trauma. - 2018. - Vol. 8 (4). - P. 77-87. PMID: 30245912

9. Нетюхайло Л. Г. Патогенез опікової хвороби (в 2 частинах) / Л. Г. Нетюхайло, С. В. Харченко, А. Г. Костенко // Світ медицини та біології. - № 1. - С. 127-135.

10. П'ятницький О. Ю. Експериментальне дослідження фармакологічних властивостей субстрату кріоконсервованої шкіри свині / О. Ю. П'ятницький, Л. В. Яковлєва, О.Ю.Кошова // Клінічна фрармація. - 2013. -Т. 17, № 1. - С. 56-62.

11. Цимбалюк А. В. Використання подрібненого субстрату ліофілізованого ксенодермоімплантата для місцевого лікування опікових хворих з інфрікованими ранами III-IV ступенів / А. В. Цимбалюк, Н. В. Гуда, О. О. Кирик // Шпитальна хірургія. - 2012. - № 1. - C. 81-84.

Отримано 03.05.19

Робота $є$ фррагментом НДР "Встановлення особливостей репаративних процесів опікової рани і морфофункціональних змін внутрішніх органів та клініко-патогенетичне обґрунтування застосування кріоліофрілізованих ксенотканин при термічній травмі". Номер державної реєстрації 0115U001531. INJURY AND IN CONDITIONS OF APPLICATION OF LYOPHILIZED XENOGRAFT SUBSTRATE

Summary. In developed countries burn injury is one of the most common type of damage in peacetime. Treatment of burns is determined by complexity and multiplicity, thermal trauma - is one of the most dangerous, it leads to the destruction of complex proteins - the basis of cells and tissues of organs. The cardiovascular system plays a key role in the development and pathogenesis of burn disease, which develops after a thermal injury of the third degree.

The aim of the study - to establish ultrastructural reorganization of atrial cardiomyocytes after severe thermal trauma and the combined application of lyophilized xenograft substrate.

Materials and Methods. Burns of the third degree were applied under ketamine anesthesia with copper plates heated in boiling water to a temperature of $97-100^{\circ} \mathrm{C}$. Euthanasia of animals was perfomed after ketamine anesthesia, by decapitation. The size of the lesions was $18-20 \%$ of the guinea pigs epilated body surface. For electron microscopic examination, atrial pieces were taken, fixed in a $2.5 \%$ glutaraldehyde solution, postfixed with $1 \%$ osmium tetraoxide solution in phosphate buffer. Further processing was carried out according to the standard technique. Ultrathin sections made on LKB-3 ultramicrotome were contrasted with uranylacetate, lead citrate according to the Reynolds method and studied with a PEM-125 K electron microscope. 
Results and Discussion. During experiment submicroscopic changes of atrial cardiomyocytes after severe thermal trauma under condition of early necrectomy and the combined application of lyophilized xenograft substrate to cover the burn wound were investigated. It was established that after burning of the III degree there are significant ultrastructural changes in atrial cardiomyocytes, the damage degree of which increased in the dynamics of the experiment. In the stages of burn shock and early toxemia adaptive-compensatory processes are developing in the structures of the heart, and in the stages of late toxemia and septicotoxemia there are deep irreversible destructive changes. It was proved that the application of lyophilized xenograft substrate after the early necrectomy of damaged tissues prevents the development of destructive changes in the components of the heart in the early stages of the experiment, activates the regenerative processes of the contractile and endocrine atrial myocytes at the late stages of the experiment.

Conclusions. The use of lyophilized xenograft substrate has a positive effect on the course of regenerative processes and improves the state of the atrial ultrastructure in the dynamics of the experiment. In the early stages of the experience of using lyophilized xenoskin, the degree of damage to the cytoplasmic membranes of atrial cardiomyocytes is reduced, and regeneration processes in the cells are activated.

Key words: atrial cardiomyocytes; ultrastructural changes; thermal trauma; lyophilized xenograft substrate.

(С. Б. Гетманюк, 3. М. Небесная, П. Г. Лихацкий, Е. Я. Шутурма

Тернопольский национальный медицинский университет имени И. Я. Горбачевского

\section{ОСОБЕННОСТИ УЛЬТРАСТРУКТУРНОЙ РЕОРГАНИЗАЦИИ ПРЕДСЕРДНЫХ КАРДИОМИОЦИТОВ ПРИ ЭКСПЕРИМЕНТАЛЬНОЙ ТЕРМИЧЕСКОЙ ТРАВМЕ И В УСЛОВИЯХ ПРИМЕНЕНИЯ ЛИОФИЛИЗИРОВАННЫХ КСЕНОДЕРМОТРАНСПЛАНТАТОВ}

Резюме. Ожоговая травма в развитых странах является одним из самых распространенных видов повреждений мирного времени. Лечение ожогов определяется сложностью и многоплановостью, термические повреждения - одни из самых опасных, они приводят к разрушению сложных белков - основы клеток и тканей органов. Ключевую роль в развитии и патогенезе ожоговой болезни, которая развивается после термической травмы III степени, играет сердечно-сосудистая система.

Цель исследования - установить закономерности ультраструктурных изменений у предсердных кардиомиоцитах после тяжелой термической травмы в условиях применении лиофилизированных ксенодермотрансплантатов.

Материалы и методы. Ожог ІІІ степени наносили под кетаминовым наркозом медными пластинами, нагретыми в кипяченой воде до температуры $97-100^{\circ} \mathrm{C}$. Эвтаназию животных проводили под кетаминовым наркозом путем декапитации. Размеры участков поражения составили 18-20 \% эпилеванной поверхности тела морских свинок. Для электронно-микроскопического исследования взяты кусочки предсердий, фиксировали в 2,5 \% растворе глютаральдегида, постсриксацию осуществляли 1 \% раствором тетраокиса осмия на фросфратнома буфрере. Дальнейшая обработка проводилась согласно общепринятой методики. Ультратонкие срезы, изготовленные на ультрамикротоме LKB-3, контрастировали уранилацетатом, цитратом свинца по методу Рейнольдса и изучали в электронном микроскопе ПЭМ-125 К.

Результаты исследований и их обсуждение. В эксперименте исследованы субмикроскопические изменения предсердных кардиомиоцитов после тяжелой термической травмы в условиях проведения ранней некрэктомии и применении лиофилизированных ксенодермотрансплантатов для закрытия ожоговой раны. Установлено, что после ожога III степени происходят значительные ультраструктурные изменения в предсердных кардиомиоцитах, степень поражения которых нарастал в динамике эксперимента. В стадиях ожогового шока и ранней токсемии в структурах сердца развиваются приспособительно-компенсаторные процессы, а в стадиях поздней токсемии и септикотоксемии - наблюдаются глубокие необратимые деструктивные изменения. Доказано, что использование лиосилизированных ксенодермотрансплантатов после ранней некрэктомии пораженных тканей предотвращает развитие деструктивных изменений в компонентах сердца в ранние сроки опыта, активизирует регенераторные процессы сократительных и эндокринных миоцитов предсердий в поздние сроки эксперимента.

Выводы. Применение лиофилизированных ксенодермотрансплантатов положительно влияет на течение регенераторных процессов и улучшает состояние ультраструктуры предсердия в динамике эксперимента. В ранние сроки опыта применения лиофилизированной ксенокожи уменьшает степень повреждения цитоплазматических мембран кардиомиоцитов предсердий, активизируются регенераторные процессы в клетках.

Ключевые слова: предсердные кардиомиоциты; ультраструктурные изменения; термическая травма; лиосилизированные ксенодермотрансплантаты.

Адреса для листування: П. Г. Лихацький, Тернопільський національний медичний університет імені І. Я. Горбачевського, майдан Волі, 1, Тернопіль, 46001, Україна, e-mail: luhatsky@tdmu.edu.ua 